\title{
海岸地下水中への揚水による塩水侵入に関する模型実験（続）
}

\section{Model Studies of Salt Water Intrusion by Pumping Up}

Hiroshi Kawabata

\begin{abstract}
Substantial quantities of ground water have been and are being withdrawn from the ground-water reservoir of the areas at near the sea in Japan. The total amount of water withdrawn from wells is termed the gross pumpage. Before the gross pumpage begins, the chloride content of the water is normally about $10-20 \mathrm{ppm}$. As the pumping up of large quantities of ground water progresses, the interface between fresh and salt water and the zone of diffusion move father and father inland in response to the withdrawal of fresh ground water.

Effects of pumping ground water caused considerable concen locally : (1) Declining ground water levels in the vicinity of pumping wells, and (2) increasing chlorid content of the water pumped from some well near the sea.

Model experiments can play an important role in the forecast of the consequences and the recognition of the states of salt water intrusion of developing aqifers having complicate stracture.

Photographs 1-16 show the states of coning up and down of the interface between fresh and salt water according to the positions of point sink (strainer), the quantities of pumpage and the flowing volumes of ground water through the media.

(1) When the point sink is situated in the salt water before pomping up, the edge of salt water retreats to the sea.

(2) In the case of poor supply of frerh water, a pumpage on the interface introduces the salt water intrusion to inland, but good supply of fresh water, same pumping up makes the edge retreat to the sea.

(3) By pumping up of large quantities of the ground water the edge goes to inland or back to the sea in accordance with the position of point sink, and the interface reaches to the point sink. And the curve of interface under the point sink is convex toward the sea.
\end{abstract}

1. まえがき

日本全国各地に扣いて公共用水源又は工業用水源としての地下水の枯渴が問題となってから久しい

* 京都教育大学 
年月が経過している。そのよらな事熊に対して種々の技術的，行政的な対策が講ぜられある程度地盤 沈下等に関しては効果が上っているよらであるが，地下水の保全といら面に対してはまだまだの感が ある。

海岸近くの地域において地下水の揚水により, その枯渴および塩水の侵入が問題となっていること は既に乏しい。塩水の侵入により工業用水, 水道水としては使用不可となり, 温泉地に打いては泉温 の低下に連なり種々の法的な糿争のもとともなっている。その対策としては海岸近く汀線に平行に淡 水の堀割をつくるとか, Recharge basin を設けるとか, 又は Diffusion well が設置されるかして いる。しかし以上のような設備をするにしてもそれに相応する各種の条件が必要となることはいらま でもなく，例光ば一度揚水した地下水を地中に注入するにせよ污染していない淡水か, 又は濾過浄化 が行われた淡水に限られ現実問題として不可能な場合が多い。New york の Long Islandに拈いて 1000 以上の Recharge well 又は Injection well が設置されているが総揚水量 430mgdに対して, 注入量は $46 \mathrm{mgd}$ で，総揚水量に対して注入量は11\%程度である。しかしこの対策により1936年に平 均海面下 35 feet の地下水面が 1965 年には土 0 から+5 feet に上昇している。

海岸地域において塩水侵入が進行中であると認められる，即ち内陸に扎いて多量の揚水が実施され， 海岸附近の被王，不王を問わず塩水混入をきたし使用不能となった地下水域，稲田の塩害による荒廃 地を 2 3実測中であるが，思いもよら烃過をとることがあるので種々の条件の下に Model を想 定して実験研究を実施したのである。室内実験を行なら場合問題となるのが相似性のことであるが一 応定性的にも短時間でみられるといら長所もあり, 地下現実にみられない様態も直視し得られ, 条件 も大略自由に変化せしめ得るので便利である。その結果をそのまま錯雑した現地の地下状態に適用し 得るとは考えてはいない。本号では前々号で報告したものの継続実験として模型実験を実施したもの でまだ完成したものではない。注入実験は今回報告しないし，目下実験中である。

\section{2. 実験装酎および方法}

実験装置は前報告の通りであるが写真を見れば判ると思う。使用した塩水の比重は都合により 1.050.のものを使用している。砂槽中の砂の粒経は $0.5 \mathrm{~mm} \sim 1 \mathrm{~mm}$ のものである。塩水は砂粒を着 色しない染料で着色してあるので淡水, 塩分境界の Interface は Darcy's low を適用しえないと一 応はみられる乱流区域を除いてその上下，前後進の変化の状態は明瞭にみられる。海岸への地下水の 流出量 $(\mathrm{Q})$ ，揚水量 $(\mathrm{q})$ はメスシリンダーとストップ・ウオッチにより計量された。この実験は室内 実験であるので淡水に関してはLine sourceが内陸近くに存在するか, 非常に豊富な地下水補給源が 近くにある場合となる。

実験において地下水の海岸への全流出量は $2.5 \mathrm{~cm}^{3} / \mathrm{s}, 5.0 \mathrm{~cm}^{3} / \mathrm{s}, 7.5 \mathrm{~cm}^{3} / \mathrm{s}, 10 \mathrm{~cm}^{3} / \mathrm{s}, 15 \mathrm{~cm}^{3} / \mathrm{s}$, $20 \mathrm{~cm}^{3} / \mathrm{s}$ と大略の目標とした。揚水は今回の場合 point sink 一つのみとし，位置は水槽の右下の角 を原点とし，即ち実地では海岸の流出点下の不透水層上を基点としている。従って point sink の位 㯰を 5-10と記せば， $\mathrm{y}$ (上方 $)=5 \mathrm{~cm}, \mathrm{x}$ (左方) $=10 \mathrm{~cm}$ に point sink があることになる。 point sink の位置は上方に $5 \mathrm{~cm}$ 毎に, 横方向に $10 \mathrm{~cm}$ 毎に䄪 35 点とっている。揭水量は $0 \mathrm{~cm}^{3} / \mathrm{s}, 2.5 \mathrm{~cm}^{3} / \mathrm{s}$, $5 \mathrm{~cm}^{3} / \mathrm{s}, 7.5 \mathrm{~cm}^{3} / \mathrm{s}, 10 \mathrm{~cm}^{3} / \mathrm{s}, 20 \mathrm{~cm}^{3} / \mathrm{s}$ に大体なるようにした。何れの量も実験中に大体の見当を

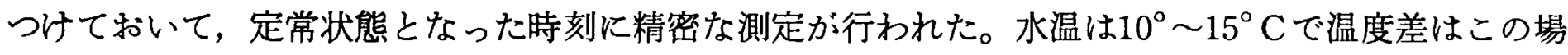
合考慮されていない。揚水方式はサィフォン式で, ピンコックにより調節が行われた。マノメーター か $10 \mathrm{~cm}$ 每に底部より立てられ水柱には淡水が入れられよくみえるよらに着色されている。

従って実験は数百通り行われたことになるが，省略された部分もある。 
この実験は二次元的なものであるので, 海岸線方向が不明であるということがあるかも知れないが 大体の想像は難くないと考劣られる。

\section{3. 実験結果ならびに考察}

実験は多種類実施されたが，そのうち代表的なものを示すことにする。淡水中の黒線は淡水中の流 線の状態をみるために染料が注入されたものが砂粒中で拡散したものである。一般の流体実験のよう に境界の明瞭な線にはならないのが残念であるが砂層中の実験では止むを得ない。

Photo. 1 に执いて $\mathrm{Q}=7.5 \mathrm{~cm}^{8} / \mathrm{s}, \mathrm{q}=0 \mathrm{~cm}^{3} / \mathrm{s}$, point sink の位置 5 - 20 である。淡水の流量が 多いらしく Interface は割合立っているようで ある。 $\mathrm{Q}=2 \mathrm{~cm}^{3} / \mathrm{s}$ 程度にすると塩水侵入 edge は左方 $50 \mathrm{~cm}$ ぐらいのところまでくる。淡水中 の流線が右上方に斜行しているがこれは塩水侵 入の影響がでているものと考えられ，その位置 ポテンシャルエネルギーの補給は Interface と 水粒子との水平方向運動エ水ルギーの消耗によ りなされている。

Photo. 2 は流出量 $\mathrm{Q}=7.5 \mathrm{~cm}^{3} / \mathrm{s}$, 揚ネ量 $\mathrm{q}=$ $2.5 \mathrm{~cm}^{3} / \mathrm{s}$, point sink 位置 5-10 の場合であ る。塩水侵入域は Photo. 1 と比較して $30 \mathrm{~cm}$ より $15 \mathrm{~cm}$ まで退行している。Interface それ自 身も原点上を除さ下降していることが認められ る。 point sinkの位置と揚水量の変化によりこ れ程の変化が塩水の侵入に関して考えられる。 淡水中の流線の傾斜は非常にゆるやかになって いる。

Photo. 3 に扰いては Photo. 2 と比較して揚 水量が 2 倍即ち $5 \mathrm{~cm}^{3} / \mathrm{s}$ となっただけである。 Interfaceの形状はこの場合ほとんど変化せず, 左方 $15 \mathrm{~cm}$ をででていた塩水侵入 edge が消失し ている。淡水中の流線は Photo. 2 よりも下降 し大体水平に近くなっている。写真の黑白より みるに水槽 $15 \mathrm{~cm}$ 以下より流入している淡水が 揚水されているようすである。流線が point sinkに吸达まれていることはないからである。

次の Photo. 4 では揚水量 $\mathrm{q}=7.5 \mathrm{~cm}^{3} / \mathrm{s}$ とな っただけで Photo. 3 と他は同一である。この 場合 Qがq と同一量となっている。Photo. 3 と比較して変化しているとみられるところで は Interfaceが少し立ってきたことと， $15 \mathrm{~cm}$ の流線が point sink に吸込まれていることで

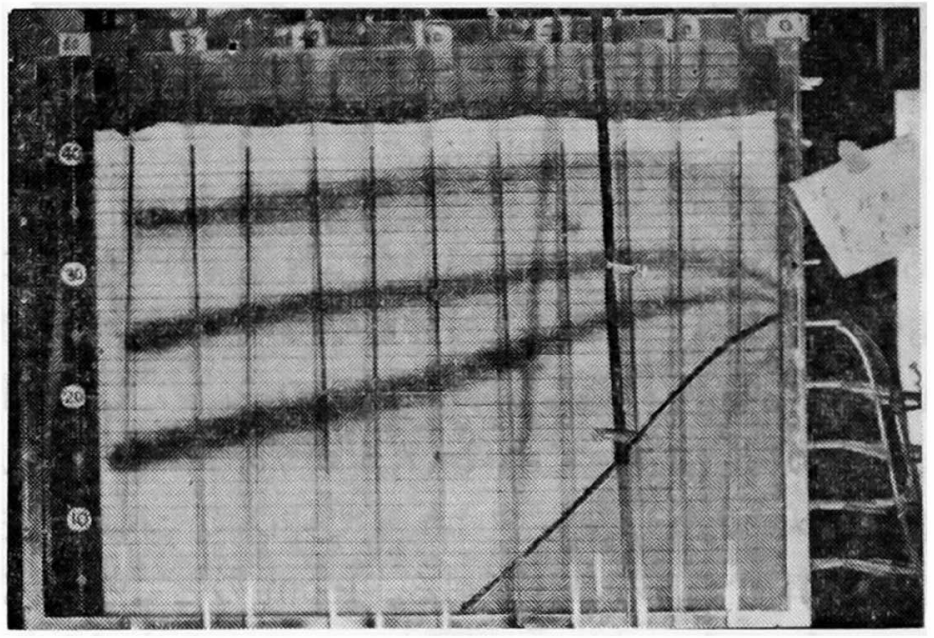

Photo. 1

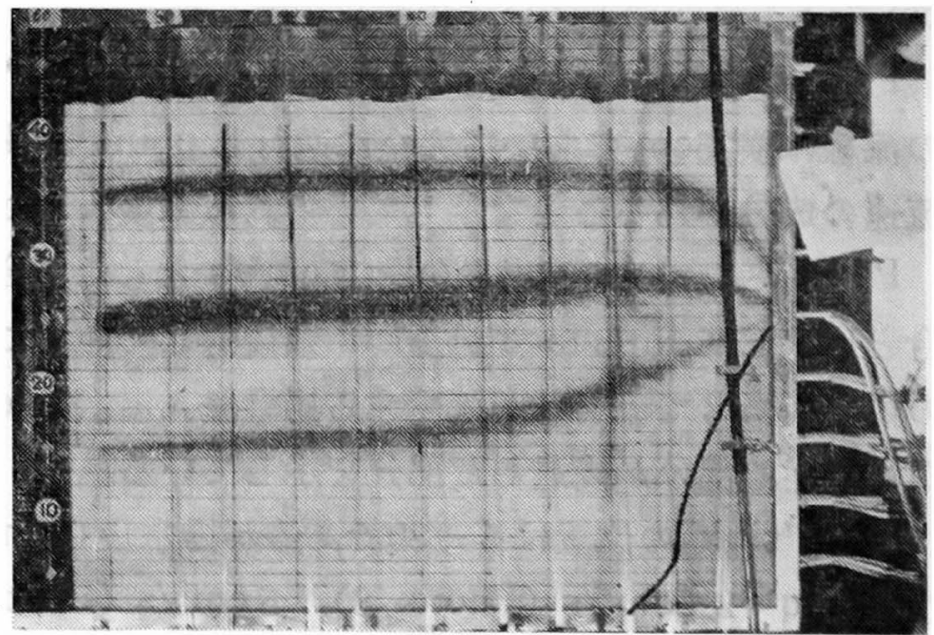

Photo. 2

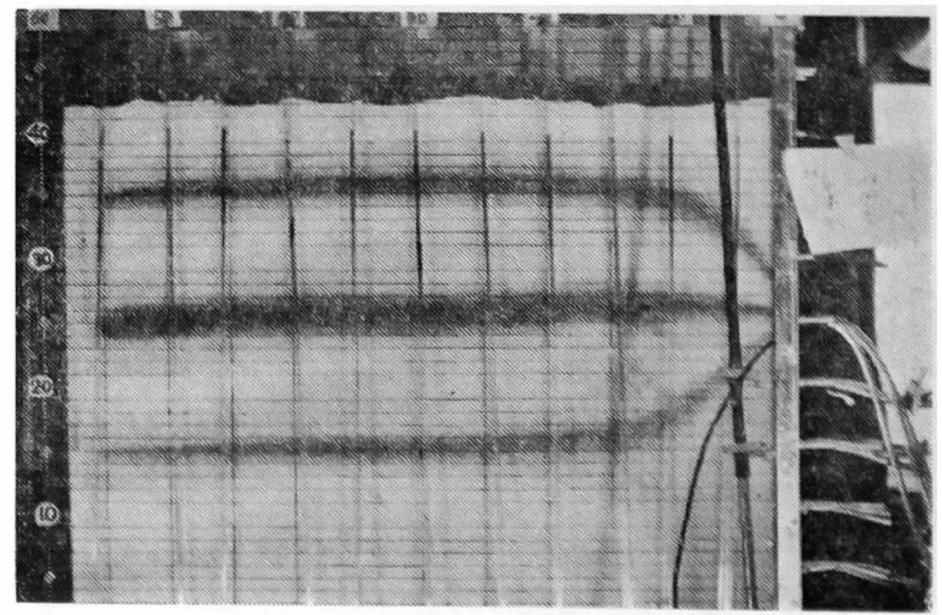

Photo. 3 


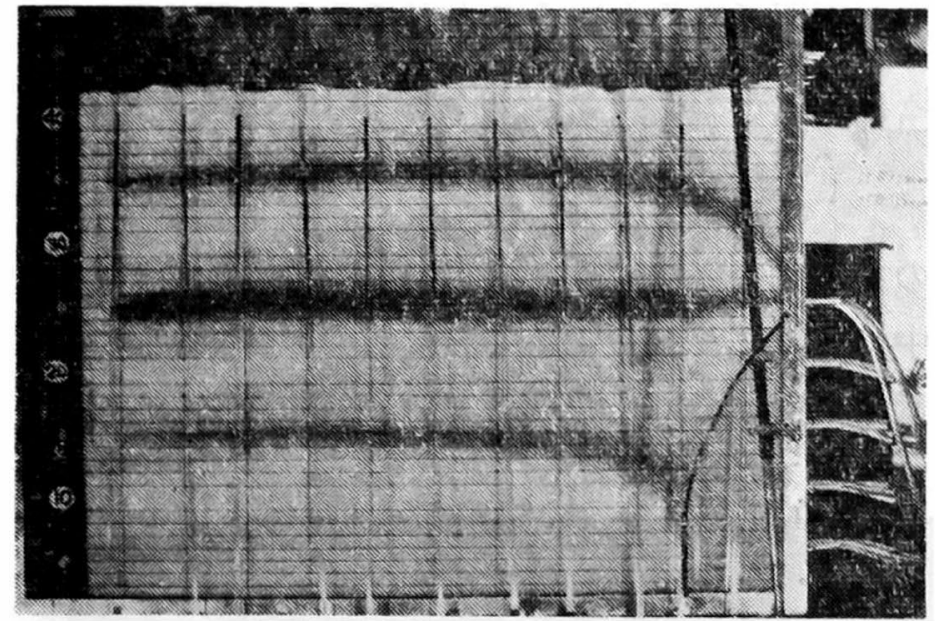

Photo. 4

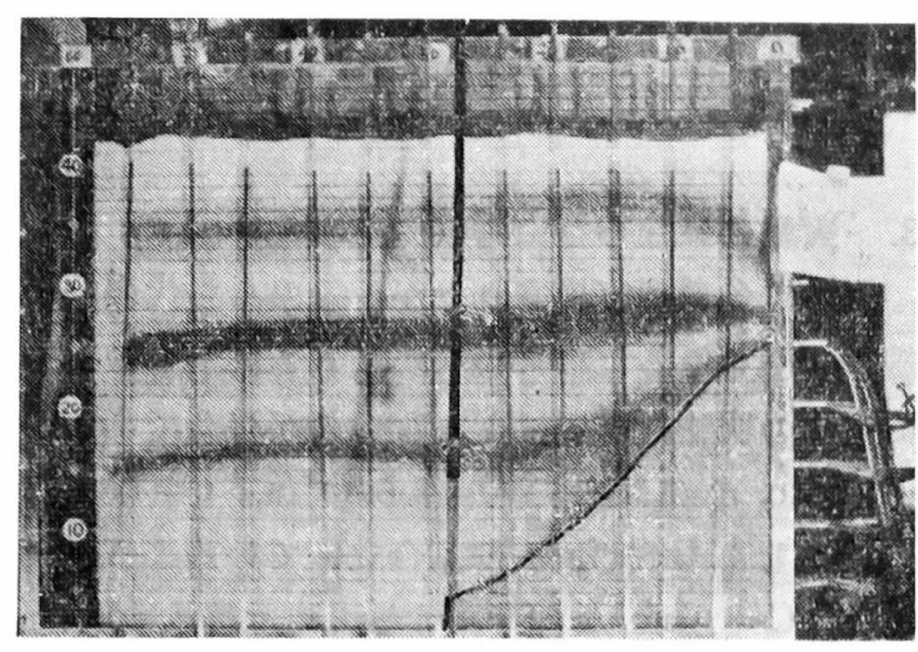

Photo. 5

ある。15mc 以下の淡水が完全に吸込まれていることを示している。この時流出量Qは変化しそうな るのであるが $15 \mathrm{~cm}$ 以上の砂層中での動水㘬配の增大によるるのかそれ程の変化は認められない。 $\mathrm{q}=0 \sim 3 \mathrm{~cm}^{8} / \mathrm{s}$ では $15 \mathrm{~cm}$ 以下の砂層の淡水の流動速度は非常にゆるやかである。

Photo. 5 においては $Q=7.5 \mathrm{~cm}^{3} / \mathrm{s}, \mathrm{q}=2.5 \mathrm{~cm}^{3} / \mathrm{s}$, point sink の位置は $5-30$ である。この場合 塩水侵入 edge は左方 $30 \mathrm{~cm}$ まで伸びてそれ以上左方には伸長しない。Interface は Photo. 1 と比較 して上䄯していることが判る。15cm のところの流線が横方向 $20 \sim 30 \mathrm{~cm}$ のところで少しく下方に弯 曲し, Interface 沿いに逆流しているようすがみうけられる。 $25 \mathrm{~cm}$ の流線も $40 \mathrm{~cm}$ まで上型し 40 ～20 $\mathrm{cm}$ で下方に弯曲しているのが見受けられる。

Photo. 6 飞执いては $\mathrm{q}=5 \mathrm{~cm}^{8} / \mathrm{s}$ とした以外 Photo. 5 と他は同一である。この時 $15 \mathrm{~cm}$ ところ の流線は横 $25 \mathrm{~cm}$ に打いて完全に逆行し point sink に流入している。 $25 \mathrm{~cm}$ に打ける流線も下降する 流速の成分があることを示している。塩水侵入の edge は $30 \mathrm{~cm}$ で直立したままである。

Photos. 7〜11 で流出量Qを $15 \mathrm{~cm}^{3} / \mathrm{s}$ とした場合前の Photos. $1 \sim 6$ の流出量 $\mathrm{Q}=7.5 \mathrm{~cm}^{3} / \mathrm{s}$ の場 合と比較して Interface が $10 \mathrm{~cm}$ 余後退していることが判る。この現象は一般的なことで上流で多量 の揚水があって流出量が減少する場合侵入塩水の edge は伸長することを示している。写真に拈いて 白く見える部分が後退した部分を示している。

Point sink の位置は 5 -30であるが揚水量 $0 \mathrm{~cm}^{3} / \mathrm{s}$ の時 $17 \mathrm{~cm}$ 程度であった塩水侵入 edge が，揚 水量が $\mathrm{q}=2.5 \mathrm{~cm}^{3} / \mathrm{s}$ (Photo. 8), $5 \mathrm{~cm}^{3} / \mathrm{s}$ (Photo. 9), $7.5 \mathrm{~cm}^{3} / \mathrm{s}$ (Photo. 10) Kなるにつれ僅か

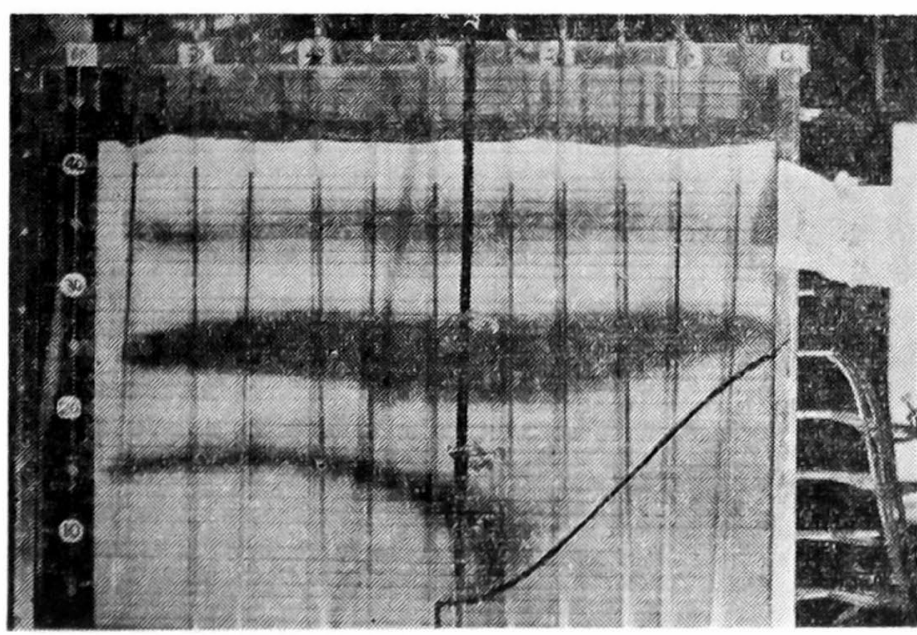

Photo. 6

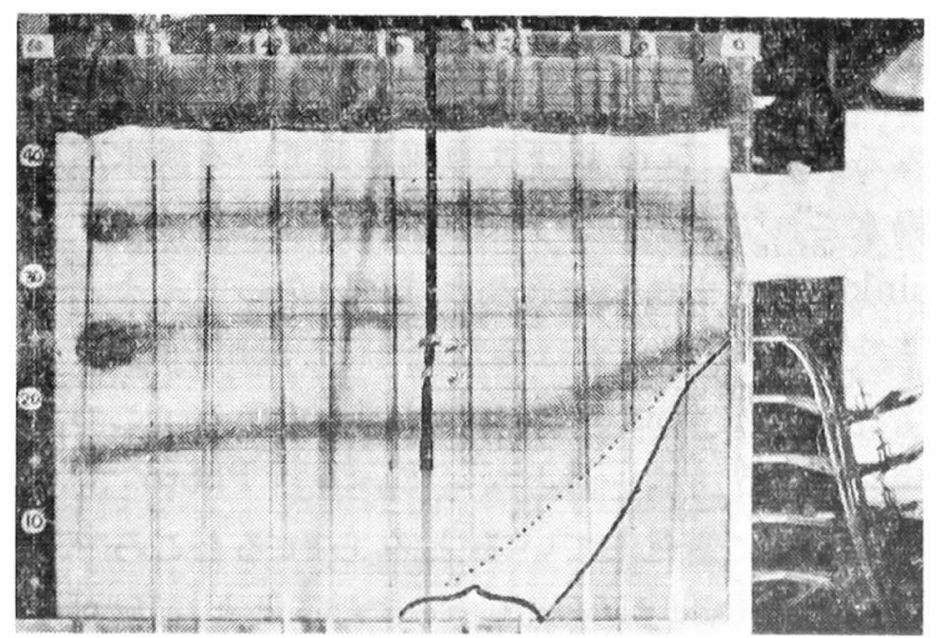

Photo. 7 
ではあるが，左方に伸びていっていることが見られる。特に Photo. 10 において塩水侵入 edge が特 異な形になっている。その上流線も特に揚水量 $\mathrm{q}=5 \mathrm{~cm}^{3} / \mathrm{s}, 7.5 \mathrm{~cm}^{3} / \mathrm{s}$ において20〜30cm 間に明瞭 に下降曲線を画き，流速にこの間下方への流速成分のあることを示している。Photo. 10 におて少 しく逆流部分があるようである。

Photo. 11 では流出量 $\mathrm{Q}=15 \mathrm{~cm}^{3} / \mathrm{s}$, 揚水量 $5 \mathrm{~cm}^{3} / \mathrm{s}$, point sink の位置 5 一20 とした場合であ る。 $20 \mathrm{~cm}$ 以遠には塩水の侵入が認められない。Interface は $20 \mathrm{~cm}$ で不連続となっている。また同 一揚水量で point sink の位置が 5 -30と比較して上䄯している。

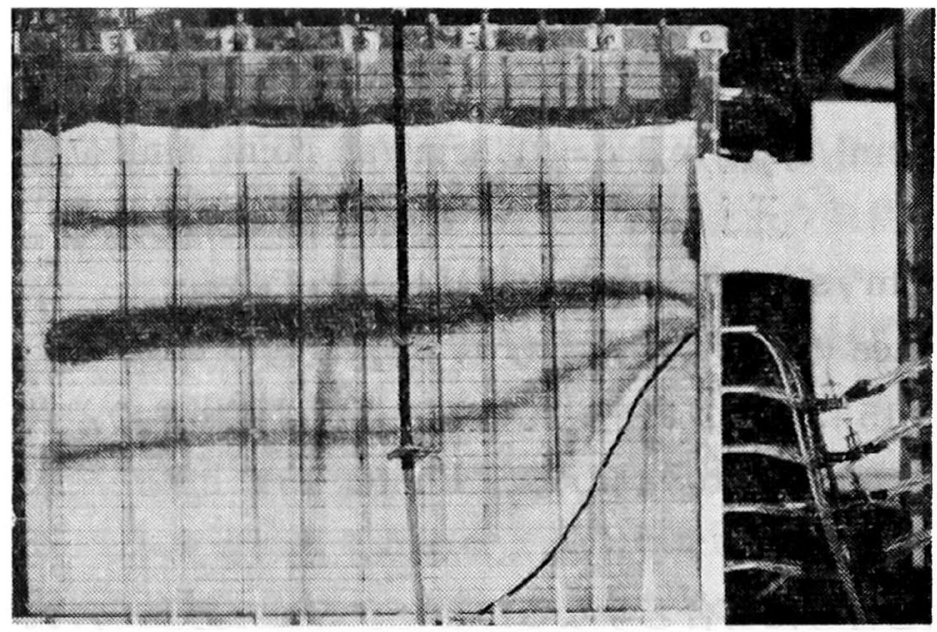

Photo. 8

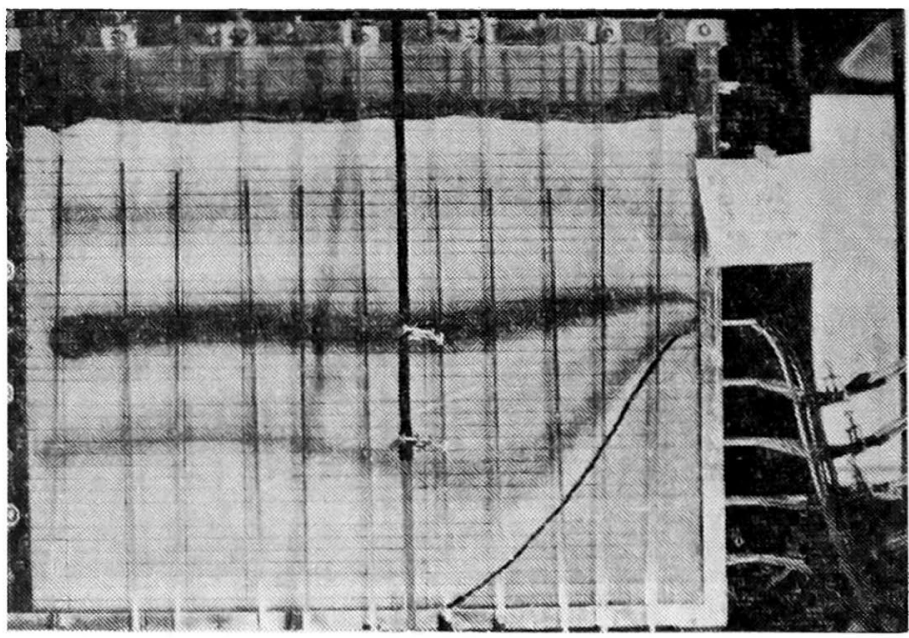

Photo. 10

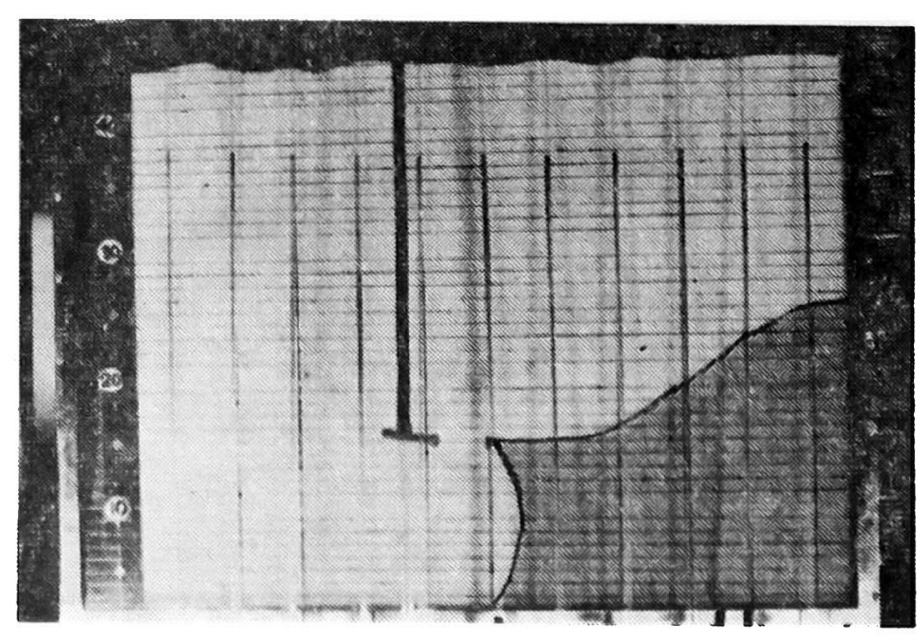

Photo. 12

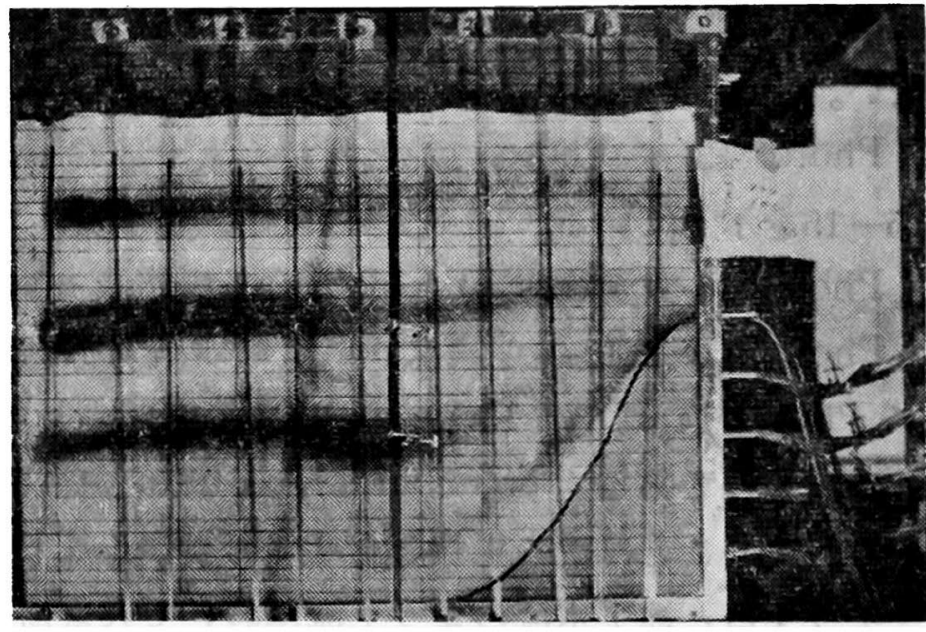

Photo. 9

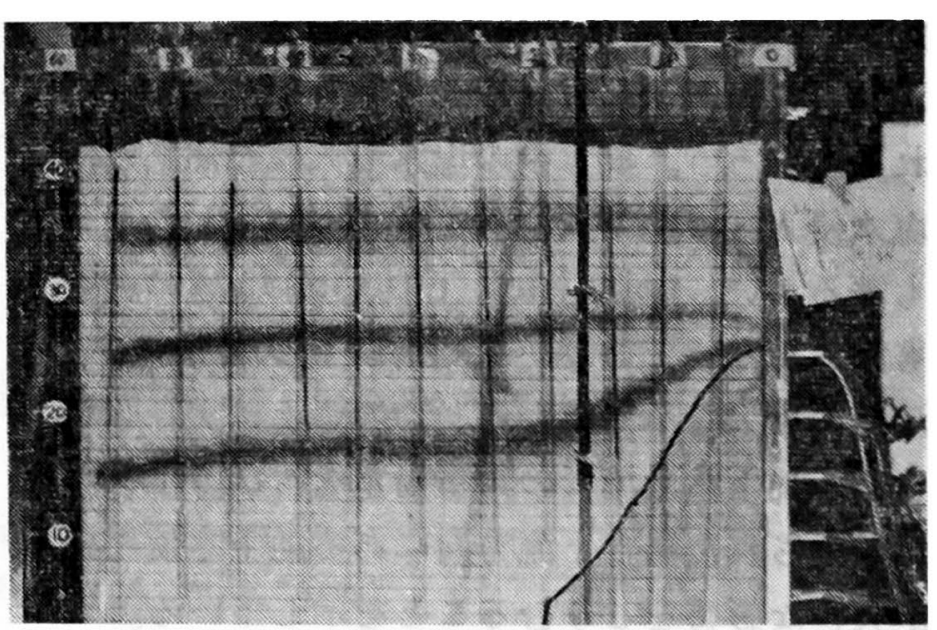

Photo. 11

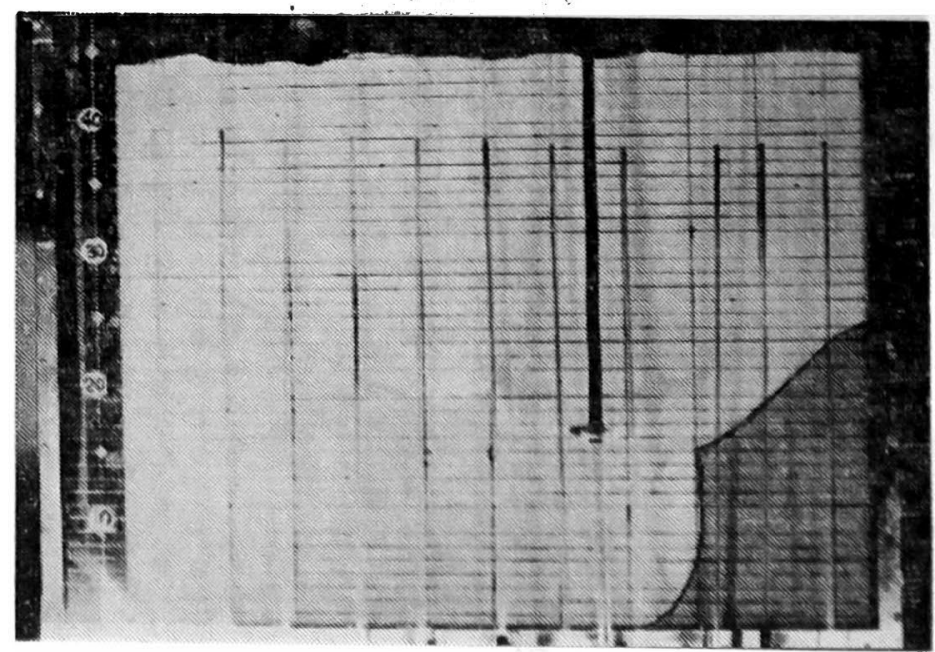

Photo. 13 
次に Photo. 12 では流出量 $\mathrm{Q}=7.5 \mathrm{~cm}^{3} / \mathrm{s}$ で揚水量を極端に増大させ $\mathrm{q}=22.5 \mathrm{~cm}^{3} / \mathrm{s}$ とした場合で ある。point sink 位置は15一30である。30cm より右におけける Interface は極端な上昇を示し，同様 の揚水量である Photos. 7〜10 と比較してその上昇ぶりが明瞭に判る。しかも $30 \mathrm{~cm}$ より左方に拈い ての塩水の侵入は認められない。従って今まで $30 \mathrm{~cm}$ より右方に敃いて地中への井戸貫入深度にもよ るが少量の揚水で塩水の混入のなかった井戸も上流での過大な揚水のある場合塩水の混入する恐れが 十分に生じることを示している。

左上万の Interface の尖端は point sink の位置を示している。しかる塩水の混入はまねかれない ことも示している。 point sink下の Interface は右の方に弯曲しているし，下端も30cm をこえてい ない。

Photo. 13 は Photo. 12 と同じく流出量 $\mathrm{Q}=7.5 \mathrm{~cm}^{3} / \mathrm{s}$, 揚水量 $\mathrm{q}=21.5 \mathrm{~cm}^{3} / \mathrm{s}$, point sink 位置 15一15を示している。

Photo. 14 は流出量 $\mathrm{Q}=15 \mathrm{~cm}^{3} / \mathrm{s}$, 揚水量 $\mathrm{q}=21 \mathrm{~cm}^{3} / \mathrm{s}$, point sink 位置は15一15である。

Photo. 14 と 15 の差異は point sink 下の Interface の形状の差異であり, 塩水侵入の edge の先 が Photo. 14 は左方 $15 \mathrm{~cm}$ 以上出ているが Photo. 15 は $15 \mathrm{~cm}$ に止っている。これは流出量の差異 によるものである。 point sink 下の Interface の曲率も Photo. 14の方が Photo. 15 に比較して大 きい。このことは次の場合と合せて考察することとする。

そうすると地下水流のより上流に拈いて大量揚水を行った場合どらなるかといらことであるが，流 出量 $\mathrm{Q}=7.5 \mathrm{~cm}^{3} / \mathrm{s}$, で揚水量 $\mathrm{q}=21 \mathrm{~cm}^{3} / \mathrm{s}$, point sink 15一45 とした場合を Phott. 15 に 示す。Photo. 1 と比較して大きな差異が見ら れるであろう。揚水中の塩水混入は当然あり,

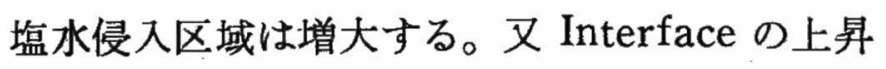
あ著るしい。 point sink下の Interface の曲率 も大きくなっており，15cm 以下の地下水流の 流速の増大を示している。このことは実際問題 として地下水上流での大量揚水を行なら工昜等 が設立された場合下流方向にある地下水使用場 が大きな影響をこらむることを示している。

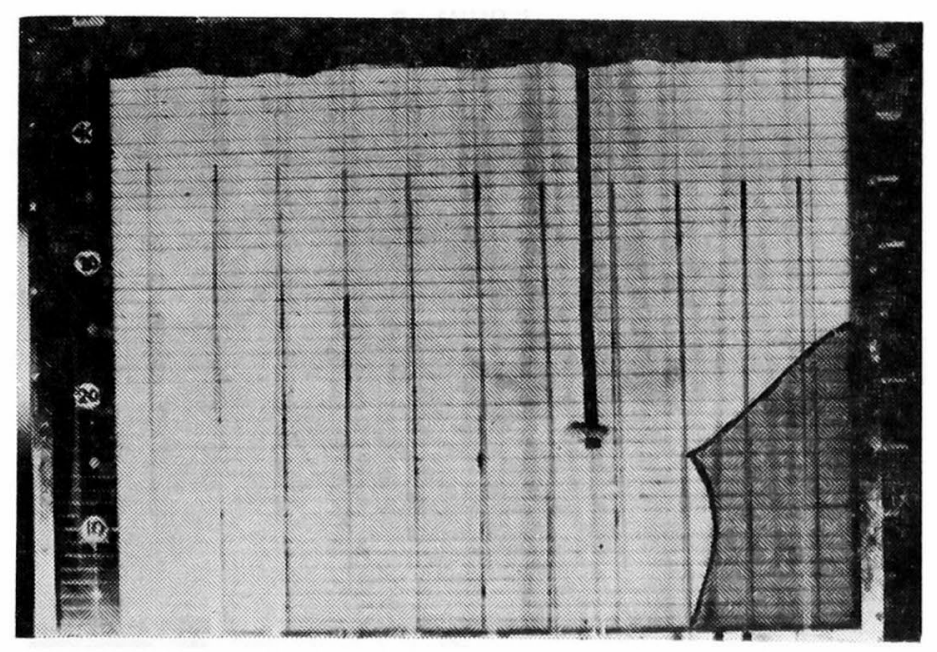

Photo. 14

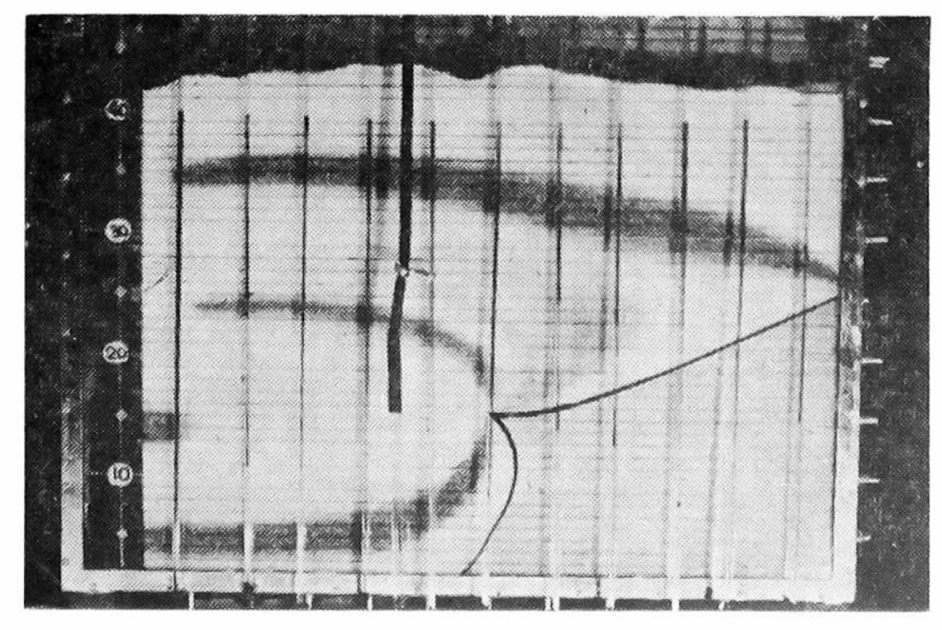

Photo. 16
Photo. 15

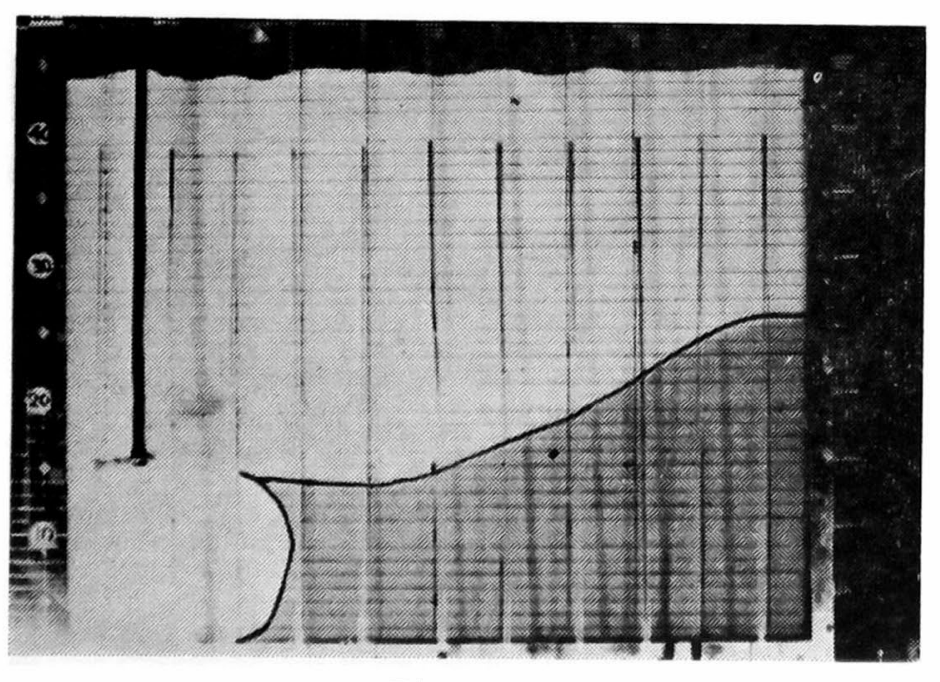


Photo. 16 飞 point sink 15 - 30 , 流出量 $\mathrm{Q}=7.5 \mathrm{~cm}^{8} / \mathrm{s}$, 揚水量 $\mathrm{q}=20 \mathrm{~cm}^{8} / \mathrm{s}$ の場合の流線を示 す。 $25 \mathrm{~cm}$ の流線が point sink 中に吸込まれていることが判る。 $35 \mathrm{~cm}$ の流線も15一 $30 \mathrm{~cm}$ 間で下方 流速成分を有していることが知れる。

Point sink 下の Interface が立って海岸方向に弯曲するのはこの場合 point sink の位置が高さ $15 \mathrm{~cm}$ にあるとすると, それ以下の地下水流の速度が大さくなり, これが Interface にあたりその運 動量が Interface に対する圧力となり，Interface を後退させ，流線に沿って弯曲させるものとみら れる。かくて両流体の圧カホテンシャルの平衡位置に止るのである。

\section{4. 桔 脸}

1. 海岸近レで淡塩水境界線（Interface）下で揚水を行らと，塩水侵入 edge を後退させ得る。揚 水中には最初塩水のみであるが淡水の割合は向上し昜合にもよるが数\%〜10\%になる。ただし この時より上流で多大な揚水のない場合で相対的な問題となる。

2. 地下水流の上流での大量揚水は塩水の侵入域の增大をもたらすが，その揚水地点以上には及ば ない。

3. 淡水（地下水）の補給のよい場所では適当な揚水は塩水侵入 edge を後退させ得る。

4. 上流での揚水は揚水点下の Interface は海岸方向に弯曲する。

以上の実験報告は全実験の一部で Rechage basin, Diffusion well の報告は後日とする。 な打本実験にあたり協力した本学学生奥田, 岡田両君の労を多とするものである。

\section{考考文献}

1) Henry, H. R. : Saltwater intrusion into freshwater aquifers, Journal of Geophysical Research, 64(11), 1959

2) Kashef, Abdel-Aziz L.: Model studies of salt water intrusion, Water Resources Bulletin, 6-6, 1970

3) Kawabata, H. : Study of the flow state of two layers' liquids through porous media, Bull. of Kyoto Gakugei Univ., B-16, 1960

4) Kawabata, H., : Free surface ahd interface of two liquids through porous media by pumping up, Jour. of Sci. of Hiroshima Univ., A-24-2, 1960

5) Kawabata, H. : The flowing states of undergroundwater near the sea strand, Bull. of Kyoto Gakugei Univ., B-17, 1961

6) Columbus, N. : Viscous model study sea water intrusion in water table aqifers, Water Resources Research, 1(2), 1965

7) Glover, R. E. : The pattern of fresh-water in a coastal aquifer, Jour. of Geophysical Research, 94-4, 1965

8) Glover, R. E. : A new method for predicting transient states of salinity intrusion into the Sacramento-San Joaquin Delta, Trans., American Geophysical Union, 36-4, 1955

9) Kohout, F. A. : A hypothesis concerning cyclic flow of salt water related to geothermal heating in the Flordan quifer, Trans. of the New York Academy of Sci., II-28-2, 1965

10）川端 博：揚水による塩水侵入についての模型実験，日本地下水学会会誌，15-1，1973 